\title{
Multi-criteria analysis for major road infrastructure projects. Case study: Brașov - Bacău Highway
}

\author{
PhD Student Cosmin PĂUNESCU, Ass. Prof. Robert DOBRE, \\ PhD Student Traian DRĂGHICI \\ University of Bucharest, Faculty of Geography \\ cosminpaunescugeorge@gmail.com
}

\begin{abstract}
Road infrastructure projects have proven to be a challenging task, particularly in a dynamic setting, such as mountains and hillsides. Such an endeavour entails the integration and processing of cross-disciplinary research, particularly engineering and geosciences. Our study is oriented towards the geographic aspects, specifically the ones involving applied geomorphology. We aim to provide a cartographic solution that reveals the areas suitable for developing a road network, based on a geomorphologic and environmental approach. This is achieved through a GIS-based multi-criteria analysis involving raster data sets of different geodynamic factors, such as geology, pedology, gravitational processes, land use and other environmental components.
\end{abstract}

Keywords: GIS, Road Infrastructure, Highway, Multi-criteria Analysis

\section{INTRODUCTION}

Transport infrastructure is one of the basic factors of development models of any geographical region. In the current global economic context, competitivity can be sustained through direct investments in this domain, which makes a geographical approach essential in this analytical process.

A development model requires a geomorphological survey, as it has the capacity to identify solutions with the purpose of maintaining a balance between natural and man-made environments (Dobre 2016).

The evaluation of environmental components represents the basis of such an analysis, designed to prevent the problems that may arise in the design, construction and usage of the transport infrastructure.

The area chosen for identifying the optimal route for the Brașov-Bacău highway is the one between the municipalities of Târgu Secuiesc and Onești, namely between Râul Negru and the Tazlău-Caşin depressions. These areas are bordered by a mountainous range, Nemira Hill and Măgura Cașinului, which are part of the Eastern Carpathians. The maximum altitude in the study area is Nemira Hill, with 1642 m a.s.l. (above sea level). Geologically, it mainly consists of flysch sandstone facies (Tarcău and intermediary facies) and flysch limestones. The minimum altitude lies at the bottom of the Tazlău-Cașin depression (Onești municipality) with $167 \mathrm{~m}$ a.s.1., an area consisting mainly of sedimentary rocks.

Because a geographical analysis of such a large area requires an abundance of spatial data, in the first stage we chose to focus on a sample area: the contact between the mountain range and the depression area of Oituz River. The aim is to test landscape suitability for a high-speed road in the Oituz Commune.

\section{METHODOLOGY}

The entire study is patterned on a multi-criteria analysis in which several geographical elements were introduced, like a digital elevation model DEM (based on contour lines digitized on the 1:25.000 topographical map), slope data, geological data (source I.G.R.) and land use data (Corine Land Cover 2012), see table 1.

The GIS software of choice were Ilwis 3.4 Open and ArcGIS 10.3 suite. Microsoft Office Excel 2013 was used as a .dbf file tabbed data processing software. 


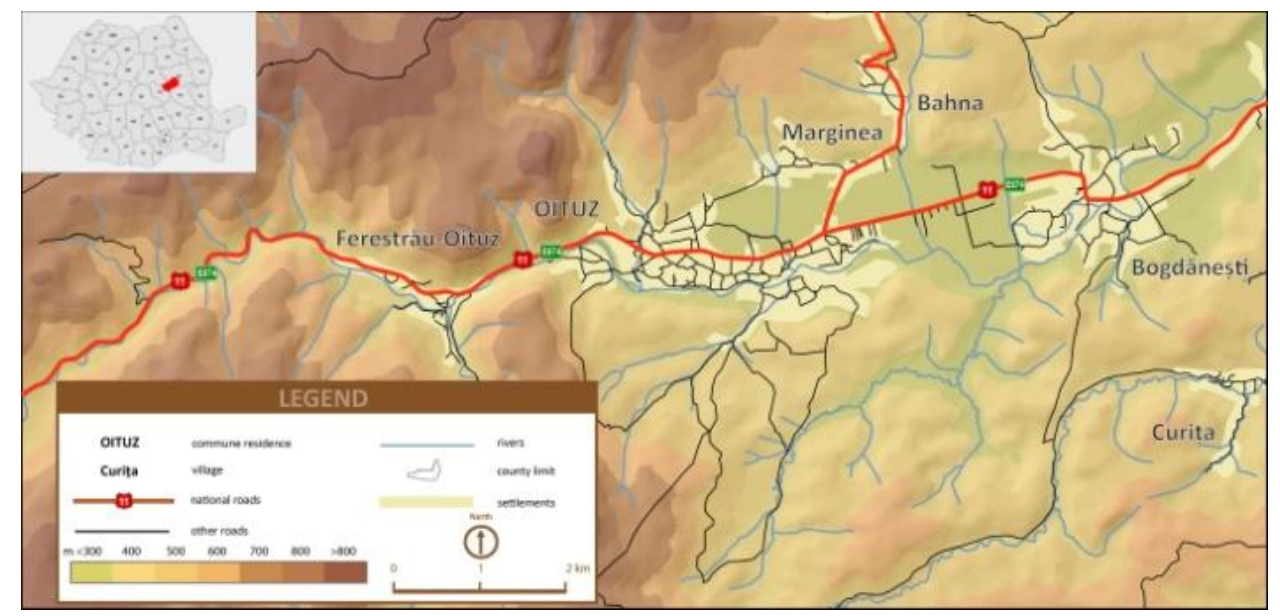

Figure 1. Study area

Table 1. Vector data used

\begin{tabular}{|c|c|c|c|}
\hline $\begin{array}{c}\text { Primary } \\
\text { data }\end{array}$ & Source & Type & Usage \\
\hline Contours & $\begin{array}{c}\text { Topographic } \\
\text { Map of } \\
\text { Romania, } \\
\text { scale } \\
1: 25.000\end{array}$ & $\begin{array}{c}\text { Line } \\
\text { vector }\end{array}$ & $\begin{array}{c}\text { DEM, slope, } \\
\text { multi-criteria } \\
\text { analysis }\end{array}$ \\
\hline Rivers & $\begin{array}{c}\text { Open Street } \\
\text { Map }\end{array}$ & $\begin{array}{c}\text { Line } \\
\text { vector }\end{array}$ & $\begin{array}{c}\text { Maps, } \\
\text { analyses }\end{array}$ \\
\hline Settlements & $\begin{array}{c}\text { Open Street } \\
\text { Map }\end{array}$ & $\begin{array}{c}\text { Polygon } \\
\text { vector }\end{array}$ & $\begin{array}{c}\text { Maps, } \\
\text { analyses }\end{array}$ \\
\hline Geology & $\begin{array}{c}\text { Geological } \\
\text { Map of } \\
\text { Romania, } \\
1: 200.000\end{array}$ & $\begin{array}{c}\text { Polygon } \\
\text { vector }\end{array}$ & $\begin{array}{c}\text { Multi-criteria } \\
\text { analysis }\end{array}$ \\
\hline Land use & $\begin{array}{c}\text { Corine Land } \\
\text { Cover 2012 }\end{array}$ & $\begin{array}{c}\text { Polygon } \\
\text { vector }\end{array}$ & $\begin{array}{c}\text { Multi-criteria } \\
\text { analysis }\end{array}$ \\
\hline
\end{tabular}

In order to create the map of relief suitability for transport infrastructure, we used a multi-criteria analysis in which a range of terrain configuration data (slope map), geological substrate and land use were introduced (Dobre 2009). Thus, in the framework of the multi-criteria analysis, each factor was given a different weight.

Each map was analysed and given a suitability value from 1 to 10 , where 1 represented a suitable area and 10 an unsuitable area. The slope map was reclassified into four classes of road infrastructure development suitability and normalized in ILWIS as follows: slopes below $10 \%$ were given the value 1 (as such slopes are considered highly suitable for road network development), slopes ranging between 10-20\% were given the value 5 (these areas are thought to have an average suitability, as they require complex road structures, e.g. embankments) and slopes over $20 \%$ were given the value 10 (such areas are deemed unsuitable, as they require highly costly road structures, e.g. tunnels).

In terms of terrain suitability, the geological factor plays a key role through structure friability and the close connection with the present-day processes that can affect the high-speed transport infrastructure in the post-construction period.

The vector dataset with geological data was simplified in the sense that the rock areas with similar characteristics were joined. Therefore, several areas resulted, which were given different suitability values (see table 2 ). Sedimentary rocks were given the value 2 , as they are favourable to human activities.

Table 2. Suitability values for geological data

\begin{tabular}{|c|c|}
\hline Geological data & Suitability values \\
\hline $\begin{array}{c}\text { Sands, gravel and leossoid } \\
\text { deposits }\end{array}$ & 2 \\
\hline Tarcău facies and flysches & 5 \\
\hline $\begin{array}{c}\text { Flysches, sandstone and } \\
\text { conglomerate facies }\end{array}$ & 5 \\
\hline Flysches and Inocerami layers & 5 \\
\hline $\begin{array}{c}\text { Sandstone, grey and red marl, } \\
\text { gypsum }\end{array}$ & 9 \\
\hline $\begin{array}{c}\text { Breccia, salt, gypsum, marl, } \\
\text { sandstone (Hârja layers) }\end{array}$ & 9 \\
\hline Grey marl, sandstone & 9 \\
\hline Clay, breccia, salt & 9 \\
\hline
\end{tabular}

Sturdier rocks such as flysch and sandstone formations were given the value 5 , as they increase the difficulty of human activities. Finally, hard 
rocks alternating with marls or clays were given the value 9 (unsuitable), as they can trigger landslides.

The land use map offers an overview of the areas suitable for the development of the transport network. In the framework of this analysis we used the Corine Land Cover 2012 dataset. The normalization process was similar to the above-mentioned factors, with suitability values from 1 to 10 , depending on the characteristics of each element on the map. The areas covered with orchards and vineyards were considered unsuitable, as they are typically located on steep slopes, the areas covered with forests and pastures were deemed moderately suitable and, finally, the areas covered by agricultural land and constructions were considered highly suitable, as they overlap with gentle slopes and have a high potential for road network development.

The terrain suitability map was created using the Spatial Multicriteria Evaluation module in Ilwis, with equal weights for each factor included in the multi-criteria analysis (slopes, geology and land use).

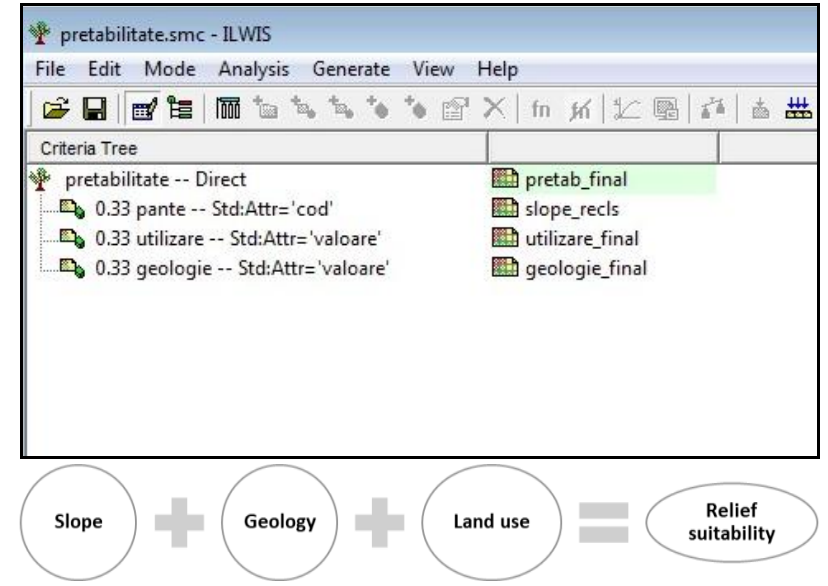

Figure 2. Methodological scheme of the relief suitability map

\section{RESULTS}

The terrain suitability map for development of manmade features, especially for the road infrastructure network, represents the weighted sum of lithological elements, geomorphologic aspects and land use data. Each of these elements have a specific impact on human activities. This kind of map emphasizes the most suitable areas for the development of human activities, specifically for the development of the transport infrastructure, based on a complex spatial and multi-criteria analysis (Dobre 2009).

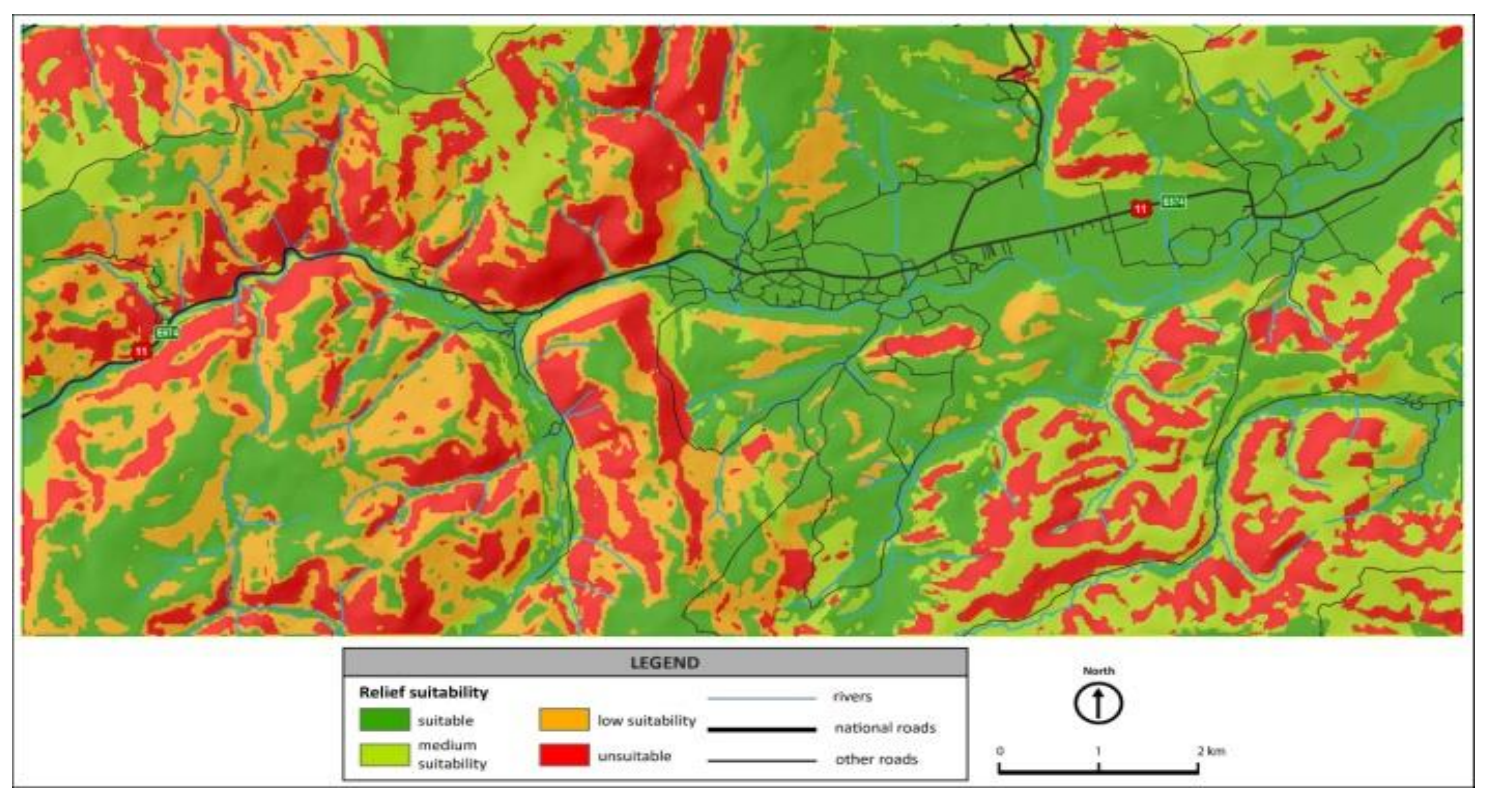

Figure 3. Terrain suitability map 
Identifying an optimal highway route through an area where multiple restrictive factors overlap, like the Oituz gorge, can prove to be a challenging task. The relief suitability map might be of use to road administrators, by highlighting restrictive and vulnerable areas, both in the project and the construction phases of the highway network. Moreover, this kind of map can provide useful information for a further project phase, especially when planning the structures of a highway (e.g. tunnels, bridges, excavations or embarkments).

All the results mentioned above were imported in ArcGIS 10.3 for validation using the Open Street Map road data and satellite imagery.

Therefore, using all the road infrastructure data and the urban areas from Open Street Map, improved with data derived from satellite imagery, we layered and intersected the obtained data with the terrain suitability map. The resulting complex index-map was validated, thus the urban areas and the road network (national, county and communal roads) being found on suitable areas (75\% of the road network). Furthermore, the map revealed that only $5 \%$ of the road network is located in unsuitable areas, most of which consist of forest roads. The only national road that intersects unsuitable areas is the National Road 11/European Road 574 in the Oituz Gorge.
Table 2. Terrain suitability - results

\begin{tabular}{|c|c|c|}
\hline Total area & $\mathbf{1 1 8 , 7 2} \mathbf{k m}^{\mathbf{2}}$ & $\mathbf{\%}$ \\
\hline Suitable & 47,92 & 41 \\
\hline Medium suitability & 21,43 & 18 \\
\hline Low suitability & 22,89 & 19 \\
\hline Unsuitable & 26,48 & 22 \\
\hline
\end{tabular}

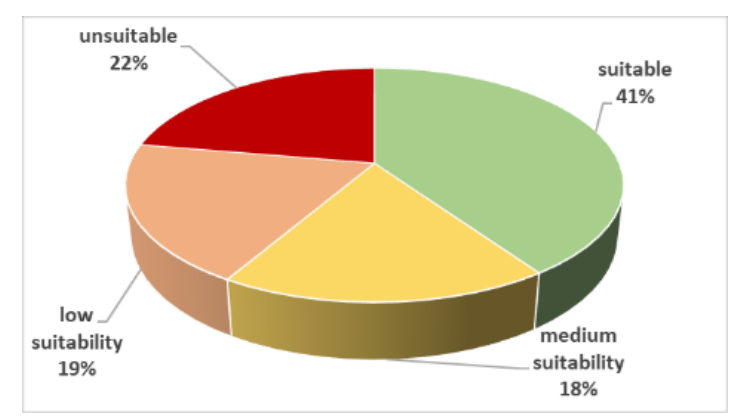

Figure 4. Relief suitability

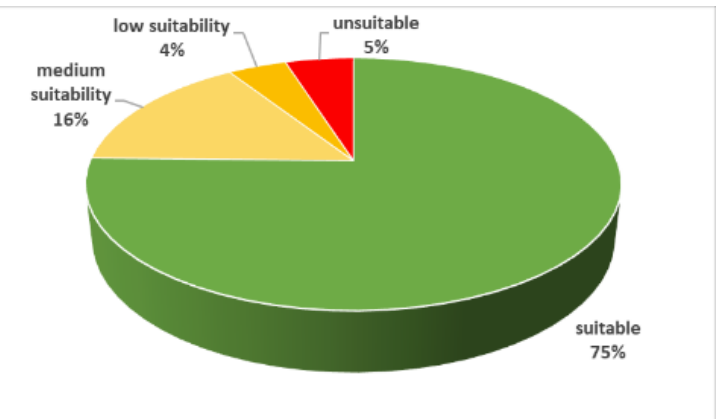

Figure 5. Intersection of road data and terrain suitability values

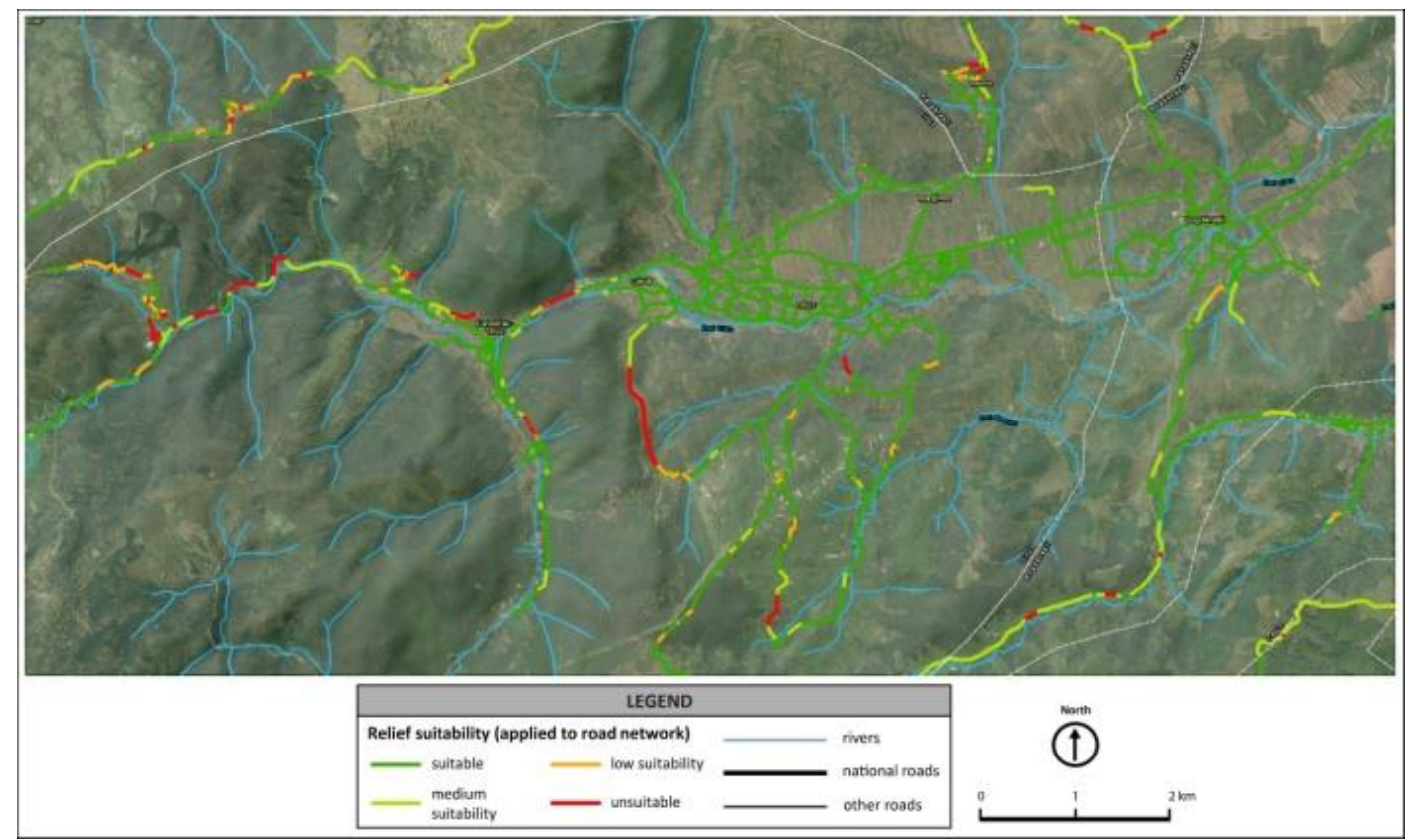

Figure 6. Intersection map of road data and terrain suitability 


\section{CONCLUSIONS}

Using the multi-criteria analysis for major road transportation projects has proven to be a useful tool for road infrastructure project preparation. This methodology can be improved by adding further spatial data regarding soil cover, social aspects and utilities (e.g. gas and water pipeline networks). The remote-sensing validation can be refined with field validation and all the results can be used for creating the most suitable highway corridors in a restrictive area.

The accuracy of this kind of analysis is ensured by the scale of data sources and by the complexity of the GIS database. By using large-scale in-field validated data, this analysis can become a trustworthy decision-making tool.

Currently, the research team is developing this methodology that can represent the basis for feasibility studies and can significantly decrease the problems that may arise both in the planning and construction phases of major road infrastructure.

\section{REFERENCES}

Brunsden, D., Doornkamp, J. C., Fookers, P. G., Jones, D. K. C., Kelly J. M. H., (1975), Geomorphological mapping techniques in highway engineering, Journal of the Institution of Highway Engineer, Volume 22

Dobre, R., (2009), Pretabilitatea reliefului pentru căi de comunicație și transport în Culoarul Prahovei, Romania, Editura Universitara

Dobre, R., (2016), Relația dinamica reliefului infrastructura de transport, Romania, Editura Etnologica

Dobre, R., Mihai, B., Savulescu, I., (2011), The Geomorphotechnical Map: a highly detailed geomorphic map for railroad infrastructure improvement. A case study for the Prahova River Defile (Curvature Carpathians, Romania), Journal of Maps, Volume 7, DOI: 10.4113/jom.2011.1155

Geneletti, D., et. al., (2002), A multi-scale approach to assess the impacts of roads on biodiversity and geomorphology, Terra Nostra 04/2002

Keller, S., Atzl, A., (2014), Mapping Natural Hazard Impacts on Road Infrastructure - The Extreme Precipitation in Baden-Wurttemberg, Germany, June 2013, International Journal of Disaster Risk Science, DOI: $10.1007 / \mathrm{s} 13753-014-0026-1$

Mihai, B., Sandric, I., (2004), Relief Accessibility Mapping and Analysis in Middle Mountain Areas. A Case Study in the Postavaru - Piatra Mare-Clabucetele Predealului Mts. (Curvature Carpathians), Studia Geomorphologica Carpatho-Balcanica, Volume 37 